IRA-International Journal of Education \&

Multidisciplinary Studies

ISSN 2455-2526; Vol.09, Issue 03 (December, 2017)

Pg. no. 30-43

Institute of Research Advances

http://research-advances.org/index.php/IJEMS

\title{
A Design of Translation Exercise in the Teaching of E-C/C-E Translation at the Undergraduate Level ${ }^{1}$
}

\author{
Ze'ang $\mathrm{Wu}^{1}$ \& Chuanmao Tian $^{2}$ \\ ${ }^{1,2}$ School of Foreign Studies, Yangtze University, Hubei, 434023 P. R. China.
}

Type of Review: Peer Reviewed.

DOI: http://dx.doi.org/10.21013/jems.v9.n3.p2

\section{How to cite this paper:}

Wu, Z., Tian, C. (2017). A Design of Translation Exercise in the Teaching of E-C/C-E Translation at the Undergraduate Level. IRA International Journal of Education and Multidisciplinary Studies (ISSN 24552526), 9(3), 30-43. doi: http://dx.doi.org/10.21013/jems.v9.n3.p2

(C) Institute of Research Advances.

\section{(cc) EY-NC}

This work is licensed under a Creative Commons Attribution-Non Commercial 4.0 International License subject to proper citation to the publication source of the work.

Disclaimer: The scholarly papers as reviewed and published by the Institute of Research Advances (IRA) are the views and opinions of their respective authors and are not the views or opinions of the IRA. The IRA disclaims of any harm or loss caused due to the published content to any party.

Institute of Research Advances is an institutional publisher member of Publishers Inter Linking Association Inc. (PILA-CrossRef), USA. The institute is an institutional signatory to the Budapest Open Access Initiative, Hungary advocating the open access of scientific and scholarly knowledge. The Institute is a registered content provider under Open Access Initiative Protocol for Metadata Harvesting (OAI-PMH).

The journal is indexed \& included in WorldCat Discovery Service (USA), CrossRef Metadata Search (USA), WorldCat (USA), OCLC (USA), Open J-Gate (India), EZB (Germany) Scilit (Switzerland), Airiti (China), Bielefeld Academic Search Engine (BASE) of Bielefeld University, Germany, PKP Index of Simon Fraser University, Canada.

\footnotetext{
1 Ze'ang Wu is a postgraduate of S161 of the School of Foreign Studies, Yangtze University and Chuanmao Tian (corresponding author) is a professor of Yangtze University.
} 


\begin{abstract}
Through the literature review, interviews, case studies, classroom observation and questionnaires, this paper summarizes the present situations of translation teaching in China, studies the design of translation exercises in the teaching of E-C/C-E Translation at the undergraduate level, analyzes the relationship between written translation teaching and learning, finds out more effective translation exercises and teaching methods for both students and teachers, in order to enhance students' interest in translating by themselves, improve their translation ability and level, and cultivate more professional translators for China.
\end{abstract}

Keywords: written translation; teaching; exercise; design

\title{
1. Introduction
}

\subsection{Background of the Study}

With the rapid development of international communication, the need for qualified translators is increasing and translation teaching has to shoulder the historic mission for cultivating more qualified professional translators. Meanwhile, the problems concerning translation teaching have aroused the interest of numerous scholars and teachers. With the aim to improve the present situations of translation teaching for college students, more and more researches on it have appeared and great achievements have been made with a positive tendency towards training qualified translators. These studies mainly deal with translation theories, translation textbooks, teaching strategies, curricula, testing and education reforms of translation teaching, as discussed in Translation Teaching in China by Mu Lei (1999), A Textbook of Translation by Peter Newmark (2002), A Two-sided Conversational Framework for English-Chinese and Chinese-English Translation by Yan Peiheng (2005), and so on. All these researches have made great contributions to cultivating talented translators and interpreters.

\subsection{Significance of the Study}

The urgent demand for proficient translators in China has made translation and translation teaching quite necessary, especially for those higher education institutions with foreign departments, and it is also very significant. Translation exercise is one important and irreplaceable part of translation teaching. A good design of translation exercise can greatly help cultivate qualified translators. Meanwhile, a success in translation means that more proficient translators can contribute better to the intercommunication among the nations in the world.

\subsection{Research Questions and Methods}

Based on the analysis of the present situations of translator vacancies and research on the relationship between translation teaching and translation learning, this paper mainly focuses on putting forward some constructive suggestions on the design of translation exercise with the aim to help teach translation in class and train students in learning translation skills and theories. In this way, the research questions can be as follows:

1) What kind of translation exercise do students like?

2) How do teachers design a good translation exercise to arouse students' interest and improve their translating skills?

In order to find the answers, we have made some surveys and interviews with sophomores and juniors of the English department of Yangtze University. Then, through the analysis of the written translation syllabus and curriculum for English majors at the undergraduate level, some suggestions on making an reasonable and effective translation exercise are put forward.

\subsection{Theoretical Basis}

This paper is mainly based on the researches of translation teaching and the theoretical achievements on translation exercise which come from some famous translators' ideas on translation course setting. The following is the theoretical conception raised by Millar (cited in Nuan 1989: 6):

The task of course design is far more than the preparation of a document which outlines the content to be taught, lists essential and recommended readings and sets essay topics. The designer also needs to consider the context in which the course will be offered, effective methods for developing the necessary knowledge, skills and attitudes of students, resources required, measures of student learning and a plan for evaluating the courses at regular intervals.

\subsection{Structure of the Paper}

This paper falls into six chapters. Part One is an introduction to the study, including the background and significance of the study, research questions and methods and theoretical basis. Chapter Two is the literature review, summarizing some perspectives on translation teaching by some famous translators in China and abroad. Chapter Three is to talk about the situations of qualified translator vacancies at home and abroad. Chapter Four 
introduces translation teaching and learning. It analyzes the present situations of translation teaching, students' problems in written translation exercise, and the relationship between translation teaching and learning. Chapter Five mainly deals with the design of translation exercise in the teaching of English-Chinese (E-C) and ChineseEnglish (C-E) translation at the undergraduate level. Chapter Six is the conclusion of the study.

\section{Literature Review}

In order to get a general idea about translation and translation teaching, definitions of translation, translation teaching, and perspectives on translation by famous translators and translation scholars are introduced. Then, the problem of designing translation exercise in translation teaching is put forward at the end of this chapter.

\subsection{Definitions}

\subsubsection{Definitions of Translation}

Translation, as a subject in college, has many definitions in theoretical discussions. Dictionaries usually define it in such terms as "art or act or production of translating" (Sykes 1978: 970). Some of them give the broader sense of "an act, process, or instance of translating; a rendering from one language into another; even a change into a different substance, form, or appearance; conversion" (Webster 1976: 1254), or "to put in plainer terms, explain" (MacDonald 1972: 1372). In A Linguistic Theory of Translation, John C. Catford claims that "Translation may be defined as follows: the replacement of textual material in one language (SL) by equivalent textual material in another language (TL)" (cited in Wilss 1982: 20). The famous American translation scholar Eugene A. Nida (1993: 12) argues that "Translation consists in reproducing in the receptor language the closest natural equivalent of source language message, first in terms of meaning and secondly in term of style". He also adds that "Reproducing the message" requires "a good many grammatical and lexical adjustments" (Nida and Taber 1969: 13). Then, he further argues that "Translation is far more than a science. It is also a skill, and in the ultimate analysis, fully satisfactory translation is always an art" (ibid.: 14). Peter Newmark (2002: 6) claims it as follows:

Translation is first a science, which entails the knowledge and verification of translation of the facts and the language that describes them -- here, what is wrong, mistakes of truth, can be identified; secondly, it is a skill, which calls for appropriate language and acceptable usage; thirdly, an art, which distinguishes good from undistinguished writing and is the creative, the intuitive, sometimes and the inspired, level of the translation.

Definitions of translation are abundant in previous translation studies. Different people hold their own ideas but the common point that they hold is that they define translation from a very theoretical point. Therefore, we agree that people should not only respect others' ideas on translation but also have their own view on translation.

\subsubsection{Definition of Translation Teaching}

Translation teaching refers to the cultivation of professional translators or interpreters, which places translation lessons under the guidance of translation theories in order to improve students' translation skills and strategies. It is the higher stage of English teaching, which is closely linked to professional translation (Zhang 2008: 8).

\subsection{Perspectives on Translation and Translation Teaching}

In recent years, researches on translation theory and practice have been expanding translation research to various areas. A great number of books, journals and international professional institutions and organizations have been established around the world. Consequently, with the increasing growth of translation studies, viewpoints and studies on translation teaching have been diversified and proposed. The following are some famous professional translators' perspectives on translation and translation teaching.

In Current Situation and Reform in Translation Teaching in China, written by Zhuang Zhixiang (1992: 1017), it can be seen that there appeared two different viewpoints on the issue of teaching translation in the 1980s. One was the theory-oriented group which insisted that systematic theories should be taught and grasped through practice. The other was technique-oriented group which held that the translation course should be mainly based on practice, and that students should be taught through a number of translation practices.

According to Yuan Binye's article entitled "A Survey of the Studies of China's Translation Teaching for Undergraduates in the Past Decades" (2003: 7-12), in the 1990s, more and more people, became aware of the importance of translation theories and began to explore translation teaching theories. Xu Lina (1997: 30) holds that translation theories should include the following content: the history of translation, the criteria of translation, definitions of translation and the process of translation, literal translation vs. free translation, translatability, translation equivalence, register, culture, and so on. Wang Shaoxiang (2002: 150) claims that "learning translation through translating" means "practice-theory-repractice". Cong Zihang (2007: 35-39) thinks that translation does not only cultivate students' translating and language abilities but also focuses more on 
cultivating students' thinking ability. Therefore, translation teaching should acknowledge the research and teaching of translation theory.

In the book A Textbook of Translation (2002), written by Peter Newmark, an English translation professor, he points out:

Words as well as sentences and texts have meaning, and you only deviate from literal translation when there are good semantic and pragmatic reasons for doing so, which is more often than not, except in grey texts. But that does not mean that I believe in the absolute primacy of the word. There are no absolutes in translation, everything is conditional, any principle (e.g. accuracy) may be in opposition to another (e.g. economy) or at least there may be tension between them. (Newmark 2002: Preface).

As a technique for learning foreign languages, translation is a two-edged instrument: it has the special purpose of demonstrating the learners' knowledge of the foreign language, either as a form of control or to exercise his intelligence in order to develop his competence (Newmark 2002: 7).

Mona Baker, a famous translator and interpreter in Britain, has done a great number of studies on translation theories and practices for many years. She says, "Translation has brought and continues to bring people of different cultural and linguistic backgrounds closer together, it has enabled them to share a more harmonious view of the world, and it has built bridges of understanding and appreciation among different societies" (Baker 2000: 36). Besides, she connects translation with linguistics and holds that:

Linguistics is a discipline which studies language both in its own right and as a tool for generating meanings. It's should therefore have a great deal to offer the budding discipline of translation studies; it can certainly offer translators valuable insights into the nature and function of language. This is particularly true of modern linguistics, which no longer restricts itself to the study of language per se but embraces such sub-disciplines as textlinguistics (the study of text as a communicative event, rather than as a shapeless string of words and structures) and pragmatics (the study of language in use rather than language as an abstract system). Modern linguistic theory can provide a basis for training translators and can inform and guide the decisions they had to make in course of performing their work. (ibid.: Introduction).

Another famous book entitled A New Coursebook on Chinese-English Translation is written by Chen Hongwei (1996) who has made much valuable research on C-E translation. They stress the importance of translation theory and the production under the guidance of theories. Besides, it is better to learn C-E translation from words, which does not mean separating words from language and cultural context but vice versa. To students, the production of translation is important, while the process is more important. Meanwhile, translation practice is necessary, which they think should be varied in forms with the purpose of arousing students' interest and training their way of thinking and translation abilities from different aspects, using problem-solving, discussion, translation and feedback, simple questions, blanks, multiple choice and translation comparison, and so on, in addition to the traditional practices such as lexical translation, sentence translation, paragraph translation and text translation.

In her book Translation Teaching in China, Mu Lei (1999) has studied translation from the viewpoint of history and its development, and analyzed the present situation of Chinese translation teaching, which involves the construction of discipline, syllabus, its arrangement, teaching materials, teaching methodology, test and interpreting teaching. Meanwhile, she advocates the reform of translation teaching from the angle of translation theories, suggesting that more attention be paid to the theories. She has mainly devoted her life to doing research on translation teaching from a macro-point and put forward many constructive suggestions to both students and teachers. Besides, she hopes that China's relevant departments can do something and take important measures to improve the conditions of translation teaching.

\subsection{Summary}

All in all, both domestic and foreign research achievements of written translation teaching are abundant in recent years. As far as the quantity and quality of the published translation essays are concerned, people have increasingly placed emphasis on translation teaching and translation theories and even some topics long neglected now have appeared in some scholars' research, such as the studies of the history of translation teaching concluded by $\mathrm{Mu}$ Lei. Their contributions to improving translation teaching are obvious. To some extent, translation teaching now is gradually being perfected, for more and more professional teaching methodologies are being used to train students, especially for the program of the Master of Translation and Interpreting (MTI). 
However, if we make further explorations into the contributions listed above, we may find out some problems. Almost little has been done on the design of translation exercise. Although this is a minor aspect in translation teaching, it has a very important place in translation teaching and it cannot be neglected. A good translation exercise can absolutely improve students' translation skills. We focus on this point in this research to look for an appropriate design of translation exercise, in the hope that it can help improve the development of translation teaching and the students' translation proficiency.

\section{Situations of Translator Vacancies at Home and Abroad}

With the rapid development of economy, China has played an ever increasing role in politics, economy, culture and other aspects throughout the world, creating a large number of opportunities to communicate with other countries, such as the 2008 Beijing Olympic Games and Paralytic Olympic Games, the Shanghai World Expo in 2010, and the Guangzhou Asian Games in 2010. Moreover, China has witnessed different kinds of commercial trading fairs, cultural exchanges, and international conferences. As long as there is cross-language communication among different countries, there is translation and translators. To some extent, all these events which have been successfully held are attributed to the development of translation field, and it is translation that bridges the language-culture gap between China and the outside world. Therefore, the need of qualified translators is increasing and translation teaching has shouldered the historic mission for cultivating more professional translators.

\subsection{Situation of Translator Vacancies at Home}

Along with the striding forward of the $21^{\text {st }}$ century, the demand for translation talents is increasing sharply in China and other countries. In the $21^{\text {st }}$ century, the demand for translation talents (including translators and interpreters) will increase about 12 times, compared with that at the end of the $20^{\text {th }}$ century in China and about 15 times in the developed and moderately developed countries. (Liu 2003: 8)

However, according to the survey of the number of translators in China, there are currently 60,000 certified translators. Most of them work for government departments. Beyond this threshold of quality lies the rough-andtumble market of some 500,000 practitioners. Besides, it is said that, the number of translator shortage is up to 440,000 in China, which accounts for 90 percent of all translators. The director of China National Foreign Language Training Centre, Wang Xin says that there are only 60,000 employed professional translators in China but the demand is 500,000 people (Zhong 2006). With the progress of economy, the number of the need will reach 1,000,000. On the other hand, at present, there are near 3,000 registered translation companies, most of which are very small in size; many workers in them are just part-time staff members, not professional translators. Wang also points out that translator vacancy has become an urgent problem to be solved in the development of Chinese economy and foreign communication.

While the number of translators has grown dramatically, the quality varies. Since the cross-cultural communication is a complicated issue, with varying differences in ideology, thinking modes and cultural backgrounds, how to communicate well and bring China to the outside world in a way understandable to foreigners has become quite an urgent issue for foreign language teachers and translator trainers.

In order to meet these strong needs, more universities and colleges have set up translation colleges or translation departments, while the gap between the need and the number of qualified translators and interpreters is great. Only when the Shanghai International Studies University formally announced that it would confer doctorates on translation majors in 2004, was translation studies as an independent academic discipline accepted. From then on, translation specialties and English schools with translation specialties in mainland China have amounted to 30 or so up to the year 2006.

From the above, we can see that the development of cultivating professional translators started very late and the number of translation talents is too small to satisfy China's need. Therefore, as a major place of training translation talents, classroom teaching is playing an important role. However, the fact is that undergraduate translation teaching has always been ignored and that even some researchers doubt that the necessity of translation teaching conflicts with social development needs. In mainland China, translation studies, along with language teaching, mathematical linguistics, computational linguistics, and so on, is ranked among the thirdclass academic disciplines under the applied linguistics (i.e. the second-class academic discipline) which belongs to linguistics (i.e. the first-class academic discipline) (Mu 1999: 28). To our delight, the Ministry of Education authorized for the first time the setup of undergraduate translation specialty in Fudan University, Hebei Normal University and Guangdong University of Foreign Studies (the Ministry of Education, 2006). From then on, with the aim to cultivate a large number of qualified translators and interpreters for China, more 
attention has been paid to the creativity and practical competence of translation majors, such as the newly born discipline MTI (Mu 2007).

\subsection{Situation of Translator Vacancies Abroad}

Not only more translation talents are needed in China, but also the need of qualified translators is increasing in other countries. Every year, translators in foreign countries cannot satisfy the demands when international conferences and commercial trading fairs happen in those countries (Hornby 1994). With the rapid development of WTO, the communication between countries becomes more frequent than before. While different countries have their own culture and native language, no one can master the ability of knowing all kinds of languages in the world. Thus, translators are never superfluous and needed forever (Bell 1995). This trend will be more obvious in the future.

Therefore, in order to supply the demand of translators for foreign countries, China has established the Confucius Institute in April, 2007, which focuses on spreading Chinese culture and cultivating Chinese translators to some extent. With the fast growth of China's economy, an increasing number of Chinese talents is highly demanded all over the world. However, the number of Confucius Institutes around the world is limited and Chinese talents are still in short supply now.

From the viewpoint of the published papers about translation teaching by famous translators and educators, readers could get the message of translator vacancies abroad. These people also want to help strengthen translation teaching in order to cultivate more professional translators through their researches and studies on translation and translation teaching, such as A Textbook of Translation written by Peter Newmark and In Other Words: A Coursebook on Translation by Mona Baker.

In a word, the tremendous demand for translation talents also exists in foreign countries, and the gap between the need and the number of qualified translators and interpreters is remarkable.

\section{Teaching and Learning of Written Translation}

This part presents a brief introduction to the current situation of translation teaching in China and the translation problems easily produced by students, and then analyze the relationship between translation teaching and learning.

\subsection{Present Situations of Translation Teaching 4.1.1 An Overview of Translation Teaching}

History has witnessed the gradual development of translation teaching in China, There are different situations in different times. The book Translation Teaching in China written by Mu Lei, describes the development of translation teaching very clearly. It has divided China's translation teaching into four time-periods: the period before the $20^{\text {th }}$ century, the period from 1902 to 1949 , the period from 1949 to 1976 , and the period from 1977 till now. Therefore, the present situations of translation teaching could date back to the year 1977 when the system of the University Entrance Examination was re-established (Mu 1999).

From then on, the real teaching of foreign language has become standardized. The syllabus for English majors at the undergraduate level made by China's Ministry of Education in 1979 required translation to be a compulsory curriculum. Thus, the place of translation as a subject in universities has been improved remarkably and paid more attention to. After the reform and open policy was carried out in 1978, more and more colleges and universities set up the Department of Foreign Languages. Translation teaching in mainland China at present focuses on cultivating translators at the undergraduate level and MTI (ibid.).

In recent years, translation and interpreting activities are flourishing. Translation departments, colleges and translation research institutes have been springing like mushrooms. China has carefully cultivated qualified, talented students of foreign languages. In 2006, a BA degree in translation in some universities was allowed for a trial run by the Ministry of Education. Moreover, in January 2007, the Academic Degree Committee of the State Council agreed to set up the MTI program -- one of 18 kinds of master's degrees in China (Yang 2008).

\subsubsection{A Specific Description of Translation Teaching}

In her book Translation Teaching in China, Mu Lei (1999) specifically describes the present situation of translation teaching in eight aspects. It includes discipline construction, course arrangement, textbook compilation, teaching faculty, teaching methodology, interpretation teaching, testing, and teaching research. 
Discipline construction. Translation as a course turned into a university discipline very late in China, for many universities or colleges set up their own foreign language department very late. Then, which specialty does translation belong to? The answer needs discussion by some relative national departments and those famous scholars' consensus in the translation field. Actually, there is one point they share: translation is a crosssubject comprehensive and independent discipline, which neither belongs to linguistics nor to literature, nor to any other subject. From the investigations and studies done in the recent 20 years, we can see that scholars have their own dividing methods according to their researches on the objects, the purpose, the content and methods, and so on, such as Liu Miqing, Fang Mengzhi, Yang Zijian, Tan Zaixi, and so on (Yan 2005). As far as translation studies is concerned, their classifications and divisions have provided a theoretical basis for the position of translation as a discipline.

Course arrangement. With the development of Chinese foreign language education, the course arrangement of foreign language majors has expanded from a simple language course to the field of culture, commercial trading, diplomacy, news, law, religion, economy, military, medical science, technology, and so on. Most foreign language departments, based on their different cultivating goals and under the guarantee of students' language skills at a required level, have set up the above courses, with the aim to help students not only master one foreign language but also learn one professional skill. Therefore, these students could suit the requirement of the human resources market for multi-skilled foreign language talents. From the survey, we may find that most translation courses for English majors at the undergraduate level are opened at the third year and last for one year or one and a half years.

Textbook compilation. Professor Feng Rui says that the textbook is a very important part of college education and the premise of cultivating cross-century talents (Li 2003). A good text cannot only solve many teaching problems, improve the quality of cultivating talents, but also is an important subject for teachers to do scientific research. Therefore, universities must make the textbook construction as a breach to cultivate crosscentury talents. In the process of conducting our survey, all the translation teachers expressed that "translation textbooks are different; its content is out of date; examples are very simple" and suggested that "Translators Associations should organize scholars to compile a new-content translation book in which the theories are well connected with practice, including translation history, translation theories, practical examples, translation analysis, comment and exercise.

Teaching staff. At present, the situations of translation teaching staff are as follows: young teachers are insufficient; the percentage of masters and doctors is less than a half; instructors and assistants are few; the age of translation teachers is not in a good percentage, and teachers under thirty-five are quite few; After some years, teachers above fifty all have to retire, and then the gap of demand for translation teachers will greatly increase.

Teaching methodology. According to the higher education syllabus for English majors, in translation class, theories and practices are both needed; the comparison between English and Chinese should be studied, and communicational translation skills should always be included. Besides, most translation teachers all agree that translation theories taught are based on practice and then the problems detected in practice are solved according to translation theories.

Interpreting teaching. For many years, interpreting teaching has not been paid much attention to and many universities have not yet opened interpreting class, and then the conflicts appear because students are very interested in interpreting and strongly hope to have this class. Moreover, some teachers find that time of interpreting class is very limited, only once a week in one semester, and students' ability of applying bilingualism is not strong, thus it is extremely difficult to accomplish the teaching task on time. Besides, it is pointed out that interpreting class is lack of theory system; teaching and researches are done from personal experiences, not scientific; the professional interpreters are so rare that they cannot meet the demand of the market. From this, we can easily understand China's interpreting teaching is not in a good condition.

Testing. In the process of teaching, testing is an important part, which can help us evaluate the teaching quality, judge whether students have mastered the relevant skills and whether they have the ability to comprehensively apply the learned knowledge and techniques. Testing is the main tool to weigh the achievements made by students at the end of the semester. However, it seems that there are few people caring about and doing researches on this topic and only a few papers are published, which is a disadvantage to the development of translation testing.

Teaching research. In the field of foreign language teaching in China's universities and colleges, scientific research is always a weak point. In all the foreign language researches, the achievements on linguistics and 
literature are more than those of translation, while in the translation field; translation teaching has rarely been cared about by people. The development of translation teaching studies seriously lags behind the development of linguistics and literature.

To improve the quality of translation teaching needs translation teachers' efforts, study and discussion, communication and interaction. Therefore, researches on translation teaching should be put on the top agenda by all translation teachers.

\subsubsection{Problems in Translation Teaching}

Although the translation training agencies spring like mushrooms, the overall quality of translation is not very good. On the one hand, many teachers still use very traditional methods to teach students in college but traditional Chinese foreign language pedagogy greatly lags behind modern international translation teaching methodology. Currently, Chinese translation instructors are challenged with both creating a contemporary curriculum and a workable methodology to suit the growing need.

There are still many problems that we cannot neglect and ignore. Translators are trained informally, with neither clearly-defined curricula nor a proper training methodology. Caminade and Pym (2010: 280) have reported that "Translators...have been trained informally, basically through trial and error, unstructured apprenticeship arrangements, or any of the various translating activities that accompany the study of a foreign language and culture within the Liberal Arts tradition."

On the other hand, many translation and interpreting teachers are not very clear about their objectives, nor able to select the right and good textbooks; many students complain that they do not gain enough helpful and useful knowledge from classes as a result of limited class hours for translation and interpreting, or, impractical textbooks, the design of the translation exercise or their own learning strategies, and so on. Some translation teachers work very hard and do a lot of job only to find that their students show little interest in class. What's worse, some teachers and students are disappointed with each other. On the contrary, in some classes, students are active learners, creative interpreters and competent translators. A teacher with a good foreign language teaching methodology will guide his or her class to enjoy the fun of learning and mastering English and Chinese as well as the fun of overcoming the difficulties while translating and interpreting. By appreciating, understanding and advising each other, both teachers and students could improve and enhance each other.

From the above, we can see that translation teaching meets with a number of puzzlements and difficulties and translation teachers need practical guides when they are "crossing a river by feeling stones" (Yang 2008).

\subsection{Students' Translation Problems}

In the process of translation, students tend to make some mistakes. In order to find out the problems, we will present an example, analyzing one student's translation of a source text from the grade 8 test for English majors (TEM 8) of 2003. The following is the English-to-Chinese source text (ST) in which all the sentences are numbered for discussion's convenience and the student's target text (TT).

\section{Source text:}

(1) In his classic novel, "The Pioneers", James Fenimore Cooper has his hero, a land developer; take his cousin on a tour of the city he is building. (2) He describes the broad streets, rows of houses, a teeming metropolis. (3) But his cousin looks around bewildered. (4) All she sees is a forest. (5) "Where are the beauties and improvements which you were to show me?" she asks. (6) He's astonished that she can't see them. (7) "Where! Why everywhere," he replies. (8) For though they are not yet built on earth, he has built them in his mind, and they are as concrete to him already constructed and finished.

\section{Target text:}

在他的古典小说《先锋》中, 詹姆士-库柏有他自己的英雄, 一名土地开发者, 带着他的表妹观光 一座他正在修建的城市。他描述着宽广的街道, 一排排的房屋, 拥挤的都市。但是他的表妹却惊奇地看 着四周。所有她看到的只是一片森林。“你给我看的美丽和改善在哪里呢? ”她问道。他很吃惊她看不到 它们。“哪儿? 为什么, 哪里都是啊! ”他回答道。因为它们还没有被建在地球上, 他已经将它们建在了 他的脑海里, 并且它们对他说很清晰, 好像已经建成了。

In the first sentence, the student mistakenly chooses the meaning of "classic". According to the $6^{\text {th }}$ Edition of Oxford Advanced Learner's English-Chinese Dictionary, “classic” has two basic meanings: “古典的” (classical) and “经典的, 著名的” (classic, famous). Which one is better depends on the whole content of the source text. 
According to our literary background knowledge, we know “经典的” or “著名的” is better than “古典的”. Second, it is the Chinese name of the novel The Pioneers. Many American literature researchers have given different names, such as “《先驱者》”, “《拓荒者》”, “《先锋》”, and so on. At present, “《拓荒者》” is the universally acknowledged and established Chinese version of the novel title. The one that needs attention is the translation of the author's name. Many English names have their own Chinese translations, which have already been universally accepted by the whole Chinese society. Thus, students should not change conventions. For example, the Chinese name of “Bethune” is “白求恩”, and Caesar is “凯撒”, not “西泽”. Therefore, James Fenimore Cooper should be translated into “詹姆士·菲尼莫尔·库柏”, a conventionalized Chinese version. Besides, students can refer to the E-C phonetic transcription table offered by Zhang Peiji, et al. in their textbook A Course in English-Chinese Translation (2008: 318-319). Fourth, the translation of "a land developer" given by the reference translation is “土地开发商”, while we think it is better to be translated as “土地开发者”, for the former sounds modern to some extent, and it does not quite suit the then social condition. The last part of sentence (1) is introduced by the causative verb "has" and thus should be given special attention to.

In the second sentence, the student should pay more attention to the translation of the three noun phrases. It is better to translate them into a parallel construction which greatly makes the translation faithful, expressive, and elegant. While examining the student's translation, we find their Chinese level needs improving. The third sentence basically has no problem. Though the fourth sentence is short, the problem is that students tend to translate it according to the sequence of the English sentence structure without considering that of Chinese. Thus, the target text becomes unclear and incoherent. We suggest putting the word “所” behind “她” and deleting “有” and then we get such a version: “他所看到的只是一片森林”.

"Beauties" and "improvements" are two difficulties in translating sentence (5). Students should be able to detect their deep meaning to make a proper translation. To translate these two words into “美景” and “改进了的 地方” is better. The student's translation of the sixth sentence is not professional. Of course, they need time and practice to improve and overcome these problems. We believe that, as long as students do a lot of practice to master translation skills and key points, their translations will be quite good in the near future. The difficulty in sentence (7) lies in how to translate the word "why". We think that it is an elliptic sentence. The whole sentence should be “why did you ask me such a question?”, therefore, it is better to translate it into “哪里? 为什么这样 问呢? 到处都是啊! 他回答道。”.

It is not difficult to translate the eighth sentence, but a good expression in Chinese makes translating hard, for it should conform to Chinese grammatical structure and make it sound beautiful and elegant. In this aspect, the student's Chinese language proficiency is quite important, and a high proficiency is extremely necessary in translating as well as interpreting. According to some surveys, it is shown that students often fall into the condition that they know the meaning of the source language but cannot express it clearly in another language, which is, as a Chinese saying goes, “只能意会不能言传”.

From the above analysis, the common problems frequently occurring in students' translation are concluded as follows: 1) they cannot choose the best meaning of the word; 2) they cannot fully analyze grammar structure; 3) they cannot know the differences between Chinese and Western cultures; 4) they are not well trained in translation theories and techniques; 5) their level of Chinese language ability needs improving.

To these problems, not only students but also teachers should pay more attention. On the one hand, students must force themselves to do more practice or exercise and to adjust their learning strategies. Besides, with the aim to have a good command of the native language, they could read some Chinese materials in every field, such as economy, politics, culture, trading, tourism, and so on. On the other hand, translation teachers also have to adjust their teaching pedagogy, to follow the steps of international development and social progress. Therefore, an increasing number of professional and qualified translators and interpreters will be cultivated.

\subsection{The Relationship between Written Translation Teaching and Learning 4.3.1 General Relationship between Teaching and Learning}

Teaching activity is a bilateral activity of teaching and learning, including both teachers and students (Marrison and Robert 2003). In the process of translation teaching, the two main subjects should express their ideas, communicate or interact with each other successfully in order to understand each other well and academically grow up together. 
Generally speaking, the relationship between teaching and learning is actually that between teachers and students or between instruction and study. In the activity of teaching, teachers and students together form a whole part through their commissions. This relationship is not a simple and linear relation of one subject to another, but the netlike relationship, as an interlaced organization or system. Their interaction happens simultaneously during the teaching activity, and they depend on each other to fulfill themselves (Deng 2000: 268). In the process of teaching activity, the student is the centre with the premise that the teacher is the instructor who has to guide students to carry out self-study; to design a favorable learning atmosphere and to prompt the teaching progress and mode reforms; to help students find their own study strategies. In this way, the student will be the central part.

Actually, the relationship between teaching and learning could also be found in many language teaching methodologies. There are such pedagogies as follows: grammar-translation methodology, direct methodology, audio-lingual methodology, cognitive-code methodology, communicative methodology, total physical response, and task-based language teaching approach. These methodologies are usually adopted to teach foreign language students; but they can also be used to teach translation, even though they may not quite be useful and necessary.

\subsubsection{The Relationship between Written Translation Teaching and Learning}

The following part introduces some traditional translation teaching methodologies. The most typical traditional translation teaching pedagogy is "master-apprentice" methodology. The teacher is the centre of translation teaching, trying their best to teach students all the fundamental knowledge and skills of translation. This method focuses on unilateral teaching, neglecting learning by students. The most obvious weakness of this pedagogy is that it relies very much on teachers' lecturing and the blackboard; students are passive learners. This method cannot arouse students' interest in learning translation to improve their abilities in translating, and bring their potentialities into full play.

On the contrary, the contemporary higher education theory advocates that students should learn how to study by themselves, analyze and solve problems, find and create knowledge; it emphasizes independent and creative thoughts. Therefore, task-based language teaching approach comes into being with the development of society.

However, to find out a more suitable translation pedagogy is not easy, for it should not only be practical but also satisfy the conditions in which the student is the centre, while the teacher is the guide and students learn translation by translating. It does not mean to abandon translation theories; on the contrary, it emphasizes "practice-theory-practice" methodology, in which theories are always taught together with practice.

Actually, the "translation workshop" methodology put forward by Professor Jin Shenghua successfully realizes the needs of present translation teaching modes (Jin 2000). It means that the translation teacher gives students some translation tasks (or students choose by themselves); then they themselves present their own translations and evaluate them; later, they discuss together; finally, the teacher gives some suggestions and makes a summary. This methodology is helpful to promoting the teacher-student communication and cooperation, and making the class atmosphere very active and free. Therefore, translation teachers not only have to improve their own accomplishments, including the achievements of their native language and accumulation of more translation experiences, but also need to guide students according to their own characteristics and idiosyncrasies so as to bring all their potentialities into full play. Then the "translation workshop methodology" could really come into effect.

Above all, we think that teaching influences learning and vice versa. Nowadays, a great number of translation scholars are doing researches on translation teaching with the aim to find out a good translation methodology. After analyzing the relationship between teaching and learning through the discussions of some traditional translation teaching approaches, we hope that it could help both teachers and students in their future communication.

\section{The Design of Translation Exercise}

This part mainly introduces the design of translation exercise, including the general idea on translation exercise, researches on translation exercise, and the summary. And finally, some constructive suggestions are put forward for translation exercise and translation teaching.

\subsection{A General Idea on Translation Exercise}

Translation exercise is a necessary part of translation teaching, for the activity of translation teaching is realized mostly by its exercise. Translation exercise, in our opinion, includes many aspects such as translation materials 
chosen for translating, class arrangements, students' participation, teacher's evaluation, and homework. A good design of translation exercise means a reasonable and suitable organization of all the above aspects in translation teaching.

Generally speaking, in various kinds and levels of training programs, the process for handling translation exercise is almost the same: teachers provide a source text and students translate it; then the teacher evaluates their translations in class, finding and solving problems together. Every coin has two sides, thus this type of translation exercise is also no exception, characterized by both advantages and disadvantages. At present, translation teachers all are struggling to find out a good type of translation exercise for students to improve their abilities and level of translating. We therefore did some surveys and interviews on this topic with the hope of helping both teachers and students.

\subsection{Research on Translation Exercise \\ 5.2.1 Research Design}

The following researches have been done by us in the School of Foreign Studies of Yangtze University through the interviews and surveys. The four classes involved in these surveys are respectively freshmen and sophomores of English in order to obtain better and useful information from the angel of students. Besides, we carried out some interviews with juniors and seniors in order to get suggestions and criticisms on their own written translation class. The following are the key points of the survey.

Research subjects. During the research, 20 English majors were interviewed and 100 students were invited to answer the questions in the survey.

Research questions. The main purpose of this research is to construct a good translation exercise for students. The following five aspects are considered to be relevant to the research purposes and have been studied in the surveys and interviews.

1) What's your ideal written translation class from your own perspective?

2) What will you do to improve your translation skills?

3)What should teachers teach in translation class from students' perspective?

4) What's your idea on translation exercise and how should it be?

5) What are your requirements for translation teachers?

All these questions are greatly helpful to carrying out the research.

\subsubsection{Surveys of Translation Exercise}

The two surveys are both undertaken in class through the way of answering the questions mentioned above by the students. They wrote down their ideas on a piece of paper and answered the questions.

The following are some students' answers and opinions on translation teaching and the design of translation exercise.

Student 1: Translation theories taught in the process of practice are better; practical experiences are more important; teaching can be carried out with practical examples.

Student 2: Written translation teaching needs much more practice.

Student 3: Teachers should give a lot of homework on C-E/E-C translation and students evaluate their work each other.

Student 4: Teachers can be stricter with students and check their translation exercise from time to time.

Student 5: Translation materials should relate to various fields, such as politics, economy, culture, literature, advertisement, etc.

Student 6: Teachers should be passionate and active in class to arouse students' interest.

Student 7: One theory is taught with relevant exercises to practice.

Student 8: The translation exercise could be closely connected with practical and useful texts in daily life, such as the translation of advertisements and tourism texts.

Student 9: In class, teachers can spare time to communicate with individual students and give guidance to them respectively based on their own characteristics.

Student 10: The teacher can introduce to students some good books or materials related to translator training. After class, students themselves have to recite more words and read more books so as to broaden their views. 
Student 11: In class, students shall be asked to answer questions on translation theories and do translating at random to make students feel a little nervous and pay more attention to learning; the teacher prepares class testing at different times.

Student 12: There can be some translation competitions held in class.

Student 13: The teacher asks students to translate the source text within a limited time period in order to improve their translating speed.

Student 14: The first five minutes of the second class hour can be devoted to a quick translation quiz. Besides, students should also be hard-working after class.

Student 15: Teachers should be strict with students; tell them how to learn translation well in class and give some constructive suggestions.

Student 16: The relevant cultural background should be introduced in class when the teacher assigns the translation material.

Student 17: If the teacher could often encourage students to translate by themselves and praise them, students will have more passion to behave well in class.

Student 18: When teaching translation, the teacher can tell students how to analyze the complex sentence structure. Of course, students also have to learn grammar well in their spare time.

Student 19: After translation methods are taught, students must recite them and apply them well through practical examples.

Student 20: In class, it is not better for the teacher to simply teach translation theories, his or her teaching should arouse students' interest and could always discuss with students about what they want to learn in class; thus, the teaching can progress with social developments.

The above are some freshmen's and sophomores' ideas and thoughts on translation class. To some extent, they all want to learn translation well and to improve their abilities of translation under the guidance of the teacher with a good translation methodology.

\subsection{Summary}

After some interviews and surveys with English majors, we can easily see that they understand the importance of translation class and all of them hope to be skilled in translating through the hardworking by themselves and the teaching by teachers. They have not only put forward some constructive suggestions for teachers but also make a lot of requirements for themselves. All in all, their ideas can be concluded as follows:

(1) Teachers should be passionate and active in class to arouse students' interest; often encourage and praise students for their good translation; make a good arrangement for translation class; find more practical translating materials to ask students translate, and introduce cultural backgrounds for students; be stricter with students and give them a lot of homework and translation exercise, and then check it in the next class together with students; ask students to answer questions at random about translation theories or skills and methods; prepare tests at different times to check their translating level; give different students different suggestions according to their own characteristics and translating levels; teach translation theories in the process of translation practice and one theory with relevant practice to deepen students' impressions, and so on.

(2) Students should not completely depend on the teacher's teaching to improve their abilities of translation. After all, the time of translation class is very limited, therefore students should spare a lot of part time to do many translation practices; try their best to read some famous books of C-E/E-C translation, such as literary books and tourism books; learn grammar well and know how to analyze the complex sentence structure; broaden their views by contacting different kinds of books and translating materials; continuously consolidate the translating skills and methods by everyday practice; be active to ask teachers questions, for teachers are all willing to help students through their efforts; be interested in translating and learning translation; often discuss with classmates to solve their own translation problems, and so on.

A good translation teacher and an industrious student will be extremely willing to refer to the above suggestions, all of which could advance the development of translation teaching and be useful for students to gain more skills as well as help them become qualified translators to some extent. However, one point we have to stress is that not all English students are translation majors and there are fewer translation majors in most universities at the undergraduate level, therefore students may not be very anxious to gain all translation skills.

\section{Conclusion}

Since translation is a comprehensive discipline, which involves many aspects and fields, cultivation of qualified translators is a long process. This part mainly makes a conclusion of the present study on translation teaching and translation exercise. Besides, limitations and suggestions for future studies are also included. 


\subsection{A Summary of the Present Study}

Through the analysis of the present situation of translation teaching in China and other countries, the demand for qualified translators is extremely great; thus, cultivation of more professional translators for the world market is urgent. This significant project should be put on the top agenda as soon as possible. In order to fulfill the aim, translation teaching becomes very important. A good translation methodology is undoubtedly desired by both teachers and students. After the study of translation teaching and learning which consists of the current conditions of translation teaching, translation problems produced by students and the relationship between teaching and learning in this paper, we know that translation teaching is not only concerned with teachers but also needs students' cooperation and diligent working. Finally, with the aim to help find better translation pedagogy, the design of translation exercise is introduced for its significance in translation teaching through the way of interviews and surveys with English majors, in the hope that the suggestions mentioned above for both teachers and students can greatly help cultivate more qualified translators for China and the whole world.

\subsection{Limitations}

Although we conducted the present research on translation teaching and translation exercise in many aspects and analyzed the current problems, putting forward some constructive suggestions for teachers and students, there are still some limitations and problems that need to be pointed out. In the process of interviews and surveys, the questions mentioned to some extent are not too typical, and could not make students express their ideas completely on written translation teaching and learning. The other limitation of the study is that this paper mainly discusses translation exercise, and thus some other aspects are neglected, such as the course arrangement and the time of translation class every semester. They are all called for further study and investigation. Besides, as the number of interviewees is not enough to get more useful information, the suggestions given above are not too constructive and may be only helpful to those students who are strongly willing to learn translation well but of little help to lazy students.

\subsection{Suggestions for Future Studies}

With the rapid growth of economy, the demands in various fields are different at different periods, which can be described by the Chinese saying "The plan cannot catch up with the change". Though a very good translation methodology is greatly advocated at present, it could not last forever. Teachers and researchers should continuously do researches and introduce new methods for students to keep up with the development of society. Besides, translation classes should adapt to the students and encompass a variety of pedagogical approaches, laying the emphasis on pedagogic or professional activities depending on whether the sessions are aimed at undergraduate English majors. We also hope that more and more universities could pay more attention to translation teaching, and therefore cultivate more qualified translators.

\section{References}

[1] Baker, M. 2000. In Other Words: A Coursebook on Translation. Beijing: Foreign Language Teaching and Research Press.

[2] Bell, T. R. 1995. Translation and Translating Theory and Practice. London and New York: Longman.

[3] Caminade, A. and Pym, A. "Eight Steps to Curricular Change." Accessed 20 Jan. 2010. http://cndls.georgrtown.edu/view/support/resources/eightsteps.html.

[4] Hornby, M. S. 1994. Translation Studies. Amsterdam and Philadelphia: John Benjamins.

[5] Li, X. 2003. New Concepts in Curriculum Development and the ELT Reform in Compulsory Education. MA thesis. Nanning: Guangxi Teachers University.

[6] MacDonald, A. M. 1972. Chambers Twentieth Century Dictionary. London: W \& R Chambers.

[7] Marison, W. and Robert, B. 2003. Psychology for Language Teachers. Beijing: Foreign Language Teaching and Research Press.

[8] Newmark, P. 2002. A Textbook of Translation. Shanghai Foreign Language Education Press.

[9] Nida, E. A. 1993. Language, Culture and Translation. Shanghai: Shanghai Foreign Language Education Press.

[10] Nida, E. A. 1975. Science of Translation: Language. Structure \& Translation[M]. California: Stanford University Press.

[11] Nida, E. A. and Taber, C. R. 1969. The Theory and Practice of Translation. The Netherlands: E. J. Leiden.

[12] Nuan, D. 1989. Designing Tasks for the Communicative Classroom. Cambridge: Cambridge University Press.

[13] Nuan, D. 1999. Second Language Teaching \& Learning. Boston, MA: Heinle \& Heinle Publishers.

[14] Sykes, J. B. (ed.). 1987. The Pocket Oxford Dictionary of Current English (Sixth Edition). Oxford: Oxford University Press.

[15] Wang, Q. 2008. A Course in English Language Teaching. Beijing: Higher Education Press.

[16] Webster, M. 1976. Webster's Seventh New Collegiate Dictionary[M]. Springfield: G \& C Merriam Company.

[17] Wilss, W. 1982. The Science of Translation: Problems and Methods. Tubingen: Gunter Narr Verlag.

[18] Yan, P. 2005. A Two-sided Conventional Framework for English-Chinese and Chinese-English Translation. Beijing: Higher Education Press. 
[19] Zhong, S. 1997. A Handbook of Translation. Beijing: The Commercial Press.

[20] 陈宏薇. 1996. 新实用汉译英教程. 武汉: 湖北教育出版社.

[21] 陈葵阳. 2005. 从构建主义观点谈翻译课堂教学. 中国翻译, 26 (3): 78-81.

[22] 从滋杭. 2007. 翻译理论与翻译教学. 中国科技翻译, 20(1): 35-39.

[23] 邓志伟. 2000. 个性化教学论. 上海: 上海教育出版社.

[24] 范仲英. 1994. 翻译教程. 上海: 上海外语教育出版社.

[25] 龚亚夫, 罗少茜. 2003. 任务型语言教学. 北京: 人民教育出版社.

[26] 刘宓庆. 2003. 翻译教学: 实物与理论. 北京: 中国对外翻译出版公司.

[27] 刘宓庆.1991. 汉英对比研究与翻译. 南昌: 江西教育出版社.

[28] 金圣华. 2000. “翻译工作坊”教学法剖析. 翻译学报, 35(4): 67-74.

[29] 穆雷. 2007. 近 50 年中国翻译教学研究的发展与现状. 广东外语外贸大学学报, 26(5): 16-21.

[30] 穆雷. 1999. 中国翻译教学研究. 上海: 上海外语教育出版社.

[31] 穆雷. 1997. 翻译事业何以发展--翻译教学及其研究. 外国语, 38(4): 46-50.

[32] 宋光庆. 1996. 外语教学与研究了论文集. 上海: 上海外语教育出版社.

[33] 王绍祥. 2002. 关于英语专业本科翻译教学的几点思考. 四川外国语学院学报, 21(1): 17-20.

[34] 夏继梅. 2000. 影响大学英语教学质量的相关因素. 外语界, 36(4): 2-5.

[35] 徐莉娜. 1998. 关于本科生翻译测试的探讨. 中国翻译, 18(3): 33-33.

[36] 杨承淑. 1997. 谈笔译教学的原则和方法. 中国翻译, 17(1): 50-54.

[37] 杨士焯. 2002. 英语专业三年级如何提高英汉翻译技能. 中国翻译, 23(6): 55-56.

[38] 杨晓荣. 2008. 翻译专业: 正名过程及正名之后. 中国翻译, 27(2): 31-34.

[39] 袁斌业. 2003. 近十年我国应专本科翻译教学研究的回顾与评述.外语界, 40(1): 9-14.

[40] 张道真. 1995. 实用英语语法. 北京: 商务印刷馆.

[41] 张培基. 1994. 英汉翻译教程. 上海: 上海外语教育出版社.

[42] 庄智象. 1992. 翻译教学及其研究的现状和改革. 外语界, 31(1): 10-17.

[43] 中华人民共和国教育部高等学校英语专业指导委员会. 2000. 高等学校英语专业英语教学大纲. 北京: 外语教 学与研究出版社.

[44] 仲伟合. 2006. 翻译专业硕士 (MTI) 的设置--翻译学学科发展的新方向. 中国翻译, 26(1): 32-25.

[45] 周燕晖. 2007. 引导个性学习-大学英语翻译的教与学. 考试周刊, 6(20): 71-73. 